\title{
Buddhist Teaching in the Development of TVET Soft Skills
}

\author{
By Prem Prasad Sigdel \\ Tri-Chandra College, Department of English
}

\begin{abstract}
Soft skills are important aspects in technical and vocational education and training to equip employee full of ethics, moral, cooperative; as a whole to promote the production of industries. It has often been ignored deliberately as the influence of hard skills is much dominant in TVET. The focus has been oriented to produce technical manpower only so numbers of TVET graduates have remained unemployed. The problems of employee and employer have been at the peak thesedays. Staff are pioneer persons who have dealt with different sorts of problems in any organization. The misunderstanding between service provider and receiver has created problem in expanding business in the developing and underdeveloped countries. Buddhist philosophy of spirituality has been recognized as a panacea to solve such problems. We need to implant love, compassion, values and so on in employee which is also the demand of employer. Such a filial piety can solve the problem of misunderstanding among employee, employer and customer. Secondary materials have been used to develop this article and maximum authenticity has been tried to maintain while preparing the article with cross verifications of literatures.
\end{abstract} Keywords: TVET, Buddhist Teaching, Soft Skills.

DOI: $10.7176 / \mathrm{JPCR} / 51-01$

Publication date: January $31^{\text {st }} 2021$

\section{Background of the Study}

The concept of work and quality of workers has been changing along with shift in the demand of employer. At present, technical and vocational education and training (TVET) was often recognized as vocational programs only ignoring its role about the development of human attribute. The need of students and employers have been ignored deliberately though they have "to work in teams, able to communicate effectively, able to solve problems and able to manage self' (Mohd Affandi et. al., 2017, p. 62). It is possible only with the development of soft skills that help to build person's attitude or attributes. Hard skills only have been compared with the machine in which human nature has been absent. An employee needs to deal with varying needs of the customer so that the organization would get more benefit. TVET is expected to address multiple demands of an economic, social and environmental nature by helping youth and adults develop the skills they need for employment (UNESCO, 2016).

Hard skills make students technically sound so it has occupied only half of the space in this changing context. It has been taken as whole before 1980s because employer only desired technical skills; in fact human attributes had been put aside. The qualities which have been developed by hard skills have been polished by soft skills. Thus graduates need appropriate interpersonal skills to work in any organization for its promotion otherwise the qualities of employee would turn 'hard' itself (Mohd Noor, Md Tab, \& Kamarulzaman, 2017). Hard skills have been recognized well at present context still it needs coloring to make it more attractive and meaningful with soft skills. An employee should perform better adorned with various qualities for customer satisfaction and business promotion though they have offered less quality service. We need cautious, responsible, cooperative, affectionate and dutiful citizen who have the feeling of selfless. According to a report of ADB, Malaysian Employers Federation is dissatisfied with the performance of the workers in "problem-solving, communication and work ethics" though they have adequate technical qualifications (Maclean \& Pavlova, 2013, p. 65). These days we need sea-change in speaking, dealing and behaving of youths or adults as they have dealt oddly. Their dealing has crammed with rough words and styles; they aren't aware of performing sincerity to others which is an essential element of a civilized person. As a corollary, less people prefer their behavior which certainly decreases the value of them. Soft skills are indeed poorly understood, not well assessed, and all too often overlooked in policy and institutional contexts, including education, training and the workplace. (Youth employment funders group, 2017, p 4)

Certainly an amicable person has been liked by everybody as they have dealt politely and sincerely. It needs soft skills to be implanted in humans so that they could show their polite nature to others. Soft skills "refer to personality traits, social graces, facility with language, personal habits, friendliness, and optimism" (Neupane \& Pradhan, 2014, p. 48). It urges young and adult for their habitual improvement implanting positive attitudes in them. If a person is habitually erroneous, s/he can't perform well in his/her job. A workplace consists of different people with different concepts and feelings. They have come from different cultural backgrounds so that employee needs to address all these issues understanding their level and social context. If we take an example of Nepal, it is full of multicultural, multiethnic and multilingual society so an employee needs even more understanding.

Workplace misbehavior and mistreatment among workers and along with the customer or service taker becomes a serious problem these days. A customer needs to return back to the organization of being a potential 
customer. The familiarity of the workers and their harmonious behavior would promote the meaning of the organization. We can find such problems between servicer and customer mostly in the service sectors in developing countries. One of the examples can be taken in hospitals of metropolitan city and other city areas of Nepal in which the tussle arises almost daily between medical workers and patients (SOLID Nepal, 2012). The service related jobs often turn "stressful occupations" as the service providers lack friendly communication and understanding (Johan, Sarwar \& Majeed, 2017). Staffs are principal persons in any organization so we should improve their attitude first for better services. We need to train them from the starting of their career training; however the solution has often been ignored.

Buddhism is "an ethico-psychological system" that helps to build up moral character in person (Sirimanne, 2016). If a person is morally degraded, his/her work achievement is too less and customers wouldn't get satisfaction; as a fact business would be tarnished. To increase the product of any organization either service or business, we need excellent ethical manpower to handle such problems. The 'Buddha' reminds us "duties, rights, social and personal obligations which make our life full of happiness and well-being" ( $\mathrm{Ng} \&$ Yuen, 2015 p. 5). 'Buddha' is a self-conscious person who would recognize others as himself and his dealing would make positive impact while serving customers. It helps us to develop the habit of tolerance which is a must for employee. The aim of education along with the mix of Buddhism is "to prepare human resources that are competent, competitive, ethical, and devoted to national interests, while making education scientific, technical, vocational, empirical, employment and people-oriented" ( $\mathrm{Ng} \&$ Yuen, 2015 p. 5). There is a practice to combine vocational education with formal education in these days to produce manpower equipped with both sorts of skills. Most of the countries mention it in their policies which have been yet to be implemented in real practice.

\section{Research Method and Paradigm}

Qualitative approach has been followed to prepare this article. Secondary sources have been read, reflected, analyzed, compared and contrasted to get ideas. The connection between soft skills and Buddhist philosophy has been deemed a must. The literatures related to soft skills and Buddhist philosophy has been surfed with latest publications. In qualitative study, researcher will analyze the data relying on recurring theme which will address ranges of meanings and integrates the ideas of text and particular contexts (Wan Muda, et. al., 2016). An exploratory study has been done to establish the issue and to make it a genuine problem to be analyzed. Critical paradigm has been followed to identify the ideas, views, practices, and the problems of soft skills from different perspectives. In this way, a subjective approach has been adopted to have logical end of the article. Different subtopics have been developed under each heading of soft skills and its subsidiary parts and combined as a whole under soft skills of TVET. Certainly it helps us to have "a close examination of a situation and can provide unique insights into a focused issue" ( $\mathrm{Ng} \&$ Yuen, 2015, p. 3).

Secondary sources of information have been used to prepare this article. Importance of soft skills has been discussed adequately as it has been the prime element of this article. Buddhist concept of ethics, spirituality, and discipline has been used as illustrative materials to make soft skills strong and reliable. Positive aspects of Buddhist influence and its assisting role to form habits of students has been focused well. Hard skills haven't got much focus except in comparison with the soft skills though it's a subsidiary factor of this article. Hence, hard skills have been put aside deliberately. The article has tried to reveal the half of the requirement of the personnel assuming that hard skills have already been practiced.

\section{Human Capital Theory}

Theory is an important aspect of any research study as it has provided a guideline for the logical end of the project. This author has chosen human capital theory as the guideline as it has tried to analyze the Buddhist philosophy of spirituality for the development of soft skills. Human capital is recognized as wealth of a person which s/he has gained from his/her own capacity. Education, training, experience and so on are the sources of human capital. Since it is related to TVET soft skills development, it has truly contributed to increase the capacity of those persons who have engaged in such education. In other words it is an investment that a person invests to increase his/her capacity of earning (Kwon, 2009).

TVET helps in sustaining the growth and development of human capital increasing person's capacity of earning. It helps increasing the capacity of those persons enhancing them soft skills. Soft skills of TVET with meaningful and effective education prepare manpower for the labor market making them much more expert (Renold \& Caves, 2017). Human capital differs from person to person depending on investment and capacity. Certainly, the implantation of soft skills would promote their capacity which has also been the demand of present era. In particular technical and vocational education and training has played a great role to increase in human capital in the world of work (Neupane, 2013). The role played by the TVET in increasing human capital is priceless though it has lacked to include soft skills at present. Despite the importance of soft skills, the product of hard skills has also been getting valuable space in it. In a nut shell, it is claimed that "general education creates general human capital; however, creation of specific human capital is the sector of TVET" (CTEVT, 2016, p. 1). Certainly the 
success of a country depends on the quality of its human capital, not only in terms of the intellect of but also in terms of the character of its citizens (Amiruddin, et. al., 2016).

\section{Buddhist Teaching in the Development of Soft Skills}

Buddhist philosophy has focused on three major attributes like discipline, meditation and wisdom (Kund, n.d.). The above elements of Buddhist philosophy helps in the development of soft skills in any person as it has focused on bodily, verbal and mental positivity of human beings. Meditation has been widely practiced in Buddhist philosophy as a means to control human thoughts and feelings. It helps to develop positive qualities in any person who have been self controlled. It also helps in the development of mindfulness in a person to make them more systematic, cooperative, and dutiful (Tamara, 2017). It reminds duties and responsibilities of any person without harming others to get the targeted goal realizing duties. It has focused on the pursuit of clear mind or enlightenment so that a person would follow his/her duty duly. Meditation has scientific value these days which is the source of neuroscience in human. The busy life of modern denizens can be consoled by meditation as we have seen the wide practice of meditation in almost all parts of the world. It has developed positive attitudes in a person so that his life would be successful in the future. Different studies have emphasized that mindfulness has positive influence in a person's life so schools and colleges have also focused on yoga, meditation, motivation trainings and so on. Thus soft skills development has much more connection with the Buddhist philosophy as we have observed it minutely.

Buddhism has been divided into three types of schools such as: The Theravada School, Zen Buddhism, and The Vajrayana School (Filanders University, n.d.). These schools have represented the same ideology with some functional differences among them. The Theravada school has focused on personal salvation which is also considered as the oldest genre of Buddhist philosophy. Similarly, Zen Buddhism practices meditation as the means of salvation. Mostly the Japanese Buddhists have practiced it; it has the aim to develop mindfulness in person to get redemption. Likewise, Vajrayana School of Buddhism is also known as Tantrayana Buddhism; indeed it has believed on sorcery that needs personal guru who could lead others towards the path of salvation. There are different branches of philosophies and rituals of Buddhist philosophy of spirituality; however they have sprouted from the same Eight fold path of Tripitaka.

Another important feature of Buddhist philosophy is sangha that emphasizes on communal effort of living, doing and learning (LaFever, 2016). The etymological meaning of sangha is living in community and communal practices. It has focused on the importance of team work which is an important feature of soft skills in TVET. The main feature of Buddhists has to live in community and to share their problems which can be learnt from sangha. The Buddhist communities have been practicing it in their daily life as well. On the other hand, $\mathrm{Ng}$ and Yuen (2015) have preached about "engaged Buddhism" in which Buddhist Teachings can be applicable in the related field. It has made Buddhist the way of life; it helps to assimilate them with another community. They have adequate tolerance capacity in comparison to other religions towards other communities; or they have deep respect of all other human kind. Engaged Buddhism, studied in Russian context, concluded that the Buddhist have more tolerance nature for migrant worker in comparison to Christians.

In this way, Buddhism has been taken as a symbol of peace and mindfulness in these days. Mainly Buddhists have been guided by their teaching of spirituality which is invaluable for others. Mainly it has urged people to be free from hatred, lust, anger and delusion. They have been guided with certain rule of philosophies so that others would also deal like religious Gurus. Similarly the new concept of Buddhist has also been developing to make it modern or contemporary to make people realize the value of it. Luanglath (2015) has tried to connect Buddhism with modern technology of e-learning. Due to the increasing nature of Buddhist philosophy, it has been being popular among people in the world. Certainly it has created an alternative environment of learning Teaching in this era to spread it to other communities. Ultimately, the main purpose of Buddhist education is to establish peaceful mind and enhancing sound health to people.

\section{Uprising of TEVT Soft Skills}

Technical Education and Vocational Training had been promulgated in the world from Second Industrial Revolution with the aim of supplying manual manpower in the 1940s. Main motto of establishing TVET schools was to produce manual manpower needed for industries. Chiefly, TVET produces manpower for industries, health, construction and agriculture (CTEVT, 2016). Mostly it has focused on producing agricultural manpower in the developing and underdeveloped countries rather than industrial manpower. From the beginning of its history, those institutions have focused on the production of technical rather than social (managerial) manpower. Or it has been often ignored as school of labors who are only workers to be operated under supervisors. The work concept has been transformed abruptly and the value of labours has been accepted as an important element for the betterment of any institution. We need quality manpower for better performance in institutions equipped with soft skills as they are of paramount importance in a person to make them do different activities (Wan Muda et. al., 2016). Findings showed that TVET institutions did not inculcate soft skills content required for survival in self- 
employment. The job challenge is not only one of quantity but also of quality to meet the need of present situation (Murgor, 2017).

It's better to compare vocational education along with formal education to understand it well. Vocational and formal education have opposite traditions as they have focused on specific occupations and systematic scientific knowledge respectively (Maclean \& Pavlova, 2013). Hence we can see defects along with the starting of vocational education that has also guided the present scenario of labour market. So people have misunderstanding regarding the production of vocational education or it has been stereotyped in the present context.

Realizing the mistake from pure vocational education, some of the countries like Germany, Japan and Switzerland have already commenced duel system of education (Renold \& Caves, 2017). That has focused on technical manpower to be equipped with formal education. Vocational education mostly focuses on technical aspect of any work whereas formal education has empowered persons with soft skills that are needed to operate market. As a corollary, hard skills only are insufficient which have been realized from the 1990s. Vocational education had been started along with the development of Industrial Revolution; so it has been misunderstood as only the hard skills (Tikly, 2013). The need of soft skills has been realized when the rate of unemployment of vocational graduates increases. It has been thought that $72 \%$ of vocational employment is common; however, less than $50 \%$ have been employed. A research report from Nepal has proved that the graduates themselves have realized the need of soft skills of not being employed (CTEVT, 2016).

Mohd Affandi et. al. (2017) included communication, critical thinking, problem-solving, teamwork, lifelong learning, entrepreneurship, ethics and professionalism, and leadership in TVET soft skills. However other writers have taken more or less other skills under soft skills. TEVT education needs to be integrated with the general education so that a moral, cooperative and friendly person can be produced. Nowadays, an interpersonal communicative personality is the demand of time who has been full of ethics. We need well studied, well trained and well civilized person to achieve such goal of education. As a whole, the students need to show positive attitude and respect for cultural values in working to meet needs and solve problems at work. Under- and unemployment rates among the sizable youth population are some of the highest in the world due to impoverished condition of soft skills (The Mastercard Foundation, 2017). Indeed integrating soft skills in the training is a must to have improvement in traditionally emphasized technical and vocational skills (Amiruddin, et. al, 2016).

\section{Hard Skills vs. Soft Skills}

Scholars have differentiated hard skills and soft skills in TVET education as opposing yet complimentary factors. Hard skills are mostly known as the technical skills related to the production unit of any job. It has connection with productivity rather than management unit; personal behaviours, attitudes and attributes have often been ignored. In other words, we can feature it as machine like quality of personnel. On the other hand, soft skills have connection with human values, behavior and conscience. Mohd Affandi, et. al (2017) categorizes TVET skills into three different categories like human skills (generic skills), technical skills and conceptual skills. Among these three skills generic skills and conceptual skills are under soft skills and technical skill is under hard skills. Hard skills are easy to learn in comparison to soft skills as it has connection with technical parts. In contrast, soft skills are hard to develop as they have connection with human behavior, values and attitudes. Some of the persons would learn it themselves; some of them have learnt from their culture; and some of them would take formal classes to acquire such skills. Only one quality can't work well as it has addressed only half of the personal behavior; thus we need technical manpower with soft skills to get prosperity in a person (Neupane \& Pradhan, 2014). As a result, some countries in Africa fear to invest in technical education anticipating that general education would be more flexible, suitable and capable of responding to economic and labour force changes in society (Lauglo \& Lillis, 1988; Munishi, 2016)

TVET system has focused on the production of technical manpower ignoring the benefits of soft skills till date mainly in the developing countries (Jha, 2012). It has been following technical parts only unlike formal education system of the world. The positive aspect of soft skills has often been deliberately ignored by TVET programs as there was the demand of behavioral education in the underprivileged countries (CTEVT, 2016). The 'hard' part of the hard skills has been embraced with bitter reality in developing cultures. Unless they don't realize the ground reality of soft skills which we can learn from formal or theoretical education, it will remain a genuine problem in the developing countries (British Council, 2015). The tragedy is that we have got "half-baked" manpower who has neither hard skills nor soft skills (Idris \& Mbudai, 2017). Understanding the mistakes of TVET education system Idris and Mbudai have expressed sorrow that the Nigerian vocational institutions have been producing low quality manpower in comparison to street vendors. It clearly indicates the need of soft skills to be learnt by TVET students. Meanwhile soft skills is ranked top ten during an interview of research participants in Malaysia compared to academic issues which is ranked eighteen (Amiruddin, et. al., 2016; Mohamad \& Azal, 2008).

Soft skills are difficult to learn as it is related to the development of personal behavior and attitudes which can be complementary to technical skills (Neupane \& Pradhan, 2014). The debate may long last if we want to 
identify the superiority or inferiority of such etymologies. It would be like 'chicken and egg' situation. Contrary to the idea, Renold and Caves (2017) have argued the need of technical manpower only, in the study about Nepal's TVET, which has sole connection to the labour market. The workers or employee aren't only the 'engine' so that we shouldn't treat them only as workers rather they are important member of the organization. Other competencies are also important rather than technical skills for the progression of any organization.

We need to explore the issue of soft skills that could be enhanced along with the filial piety of Buddhist education system. The employee should have the feeling of fraternity towards customers, colleagues and organization as their home. Certainly all education systems have the aim to produce a cordial person decked with technical and behavioral qualities. This is the world of multidisciplinary concepts and ideas in which a person should have knowledge of different subjects. A person needs to have addressed multiple customers at the same time to cater better service. We need to implant mindfulness in personnel so it would help those to get better job in their life. As a corollary, it will help to create cooperative, helpful, gracious, compassionate and value based employee in those organizations.

\section{Employment Scenario of TVET Graduates}

According to a tracer study conducted by CTEVT (2016), a vocational council of Nepal, only $49 \%$ of its graduates were employed. Among them 5\% have been working as volunteers, most of them are from health programs, and others or $46 \%$ remained jobless. The payment is also low in industries or factories in comparison to selfentrepreneurs. The agricultural graduates have earned much high in comparison to others as they are entrepreneur themselves. It indicates the fate of underdeveloped country like Nepal in which other sectors remained yet to be developed. According to the report, health and social service sector have taken $77.15 \%$ share in the job market so most of the CTEVT graduates have remained unemployed. The recommendation suggested that they needed improvement in soft skills to get job opportunities; it was also been accepted by majority of graduates (either employed or unemployed). On the other hand, employers are also longing to hire graduates with additional knowledge and skills (Munishi, 2016). In this way, a genuine problem has been forecasted by the report because of a serious mismatch between the product of TVET and demand of market.

The number of unemployed graduates is on the increase with an estimated value of $11 \%$ of the total unemployed in Malaysia in 2005 (Amiruddin, et. al., 2016). Around 90 percent of CEOs in African state like Tanzania, as Munishi (206) laid claim that availability of key competencies among graduates including those from technical education backgrounds is extremely low. All the companies interviewed said that a lack of soft skills posed a much greater challenge than the absence of hard skills. The OECD report claimed that one in five workers in its member countries are overqualified for their positions, while at the same time similar proportions are underqualified (British Council, 2015). Employers are in the need of multitalented manpower who could deal with soft skills or abilities so that they could promote their business well. The demand of the modern era has been changing so rapidly that a person should have expertise in various streams. Mainly, problem lies in speaking, dealing and behaving of employees. According to Mohd Noor, Md Tab and Kamarulzaman (2017), candidates have problems in verbal impression so that they can't attract their employers. They have analyzed the interview taken by the Malaysian companies and concluded that most of the graduates have been rejected from interview process. It indicates a grave problem among graduates who have lacked good communication or interpersonal skills. Certainly, we can feel that employee have problems in their attitude as many incidents have proved in service and production sectors. We often listen strikes, bandhas (shut down) and other protest programs in such organizations. It happens when labours have less/no confidence to get job in other areas.

Buddhist philosophy claims that problem of mental pollution is much more serious than environmental pollution (Kung, n.d.). People are prone to evil activities when they lack discipline and wisdom in their life. Their immoral activities influence their thoughts, views and behaviors that reflect emotion rather than rationality. Personnel should be able to work with rationality to reduce conflict in any organization and to have greater satisfaction of its employers and customers (Murgor, 2017). Conflict often invites negative result which is not the wish of any employer or employee. When conflict arises, it's impossible to settle down in most of the organizations; hence jobs in private sectors in underdeveloped countries are insecure and full of doubts and suspicions. It hampers the development of the organization and personnel; ultimately it disturbs national development as well.

"What you sow that you reap" is a popular proverb which is crystal clear in TVET education system. Schools need to implant positive nature or attitudes to students to have better product. Schools either vocational or formal must have taken the responsibility to make their students responsible, dutiful, and cooperative towards society and nation. Mostly vocational schools don't teach soft skills like love, compassion, liberation so the root of education is too weak to sustain its weight (Kung, n. d.). We need to create filial piety in students so that we can produce competent manpower for the nation according to Buddhist philosophy. The knowledge which students get only from books and technical skills have no value at all. Knowledge has various dimensions so we need to disclose all those aspects to make students aware about different aspects in their life. So we need to police them with soft skills to make personnel capable to deal independently in any situation. We need to produce versatile person unlike the 
'hard' one who is fit in subject matter only. We need volatile manpower rather than so-called expert in any particular subject. It needs mindfulness in a person who can be selfless to serve the nation (Murgor, 2017). The development of soft skills is deeply intertwined with academic and technical skill development together (Youth Employment Funders Group, 2017). Technical knowledge is not keeping pace with economic growth in developing countries due to such tribulations (Munishi, 2016)

We need moral citizen with sound body and mind which has been lacking these days. Those who can win himself can be the serviceman of sentient being in the language of Buddhism. The practice of TVET these days is missing somewhere on the production of quality manpower full of filial piety. Only with the endorsement of Buddhist education, we can make citizens more responsible, compassionate, affectionate, liberated and full of joy. Such a person can get better achievement in comparison to those who have been equipped with technical/hard skills only. We need to clear our mind first to make our body healthy and sound. Bad thoughts and ideas develop crooked habit and the person isn't liked by others. The production of good person is possible only with the development of soft skills in our life.

The purpose of any person is to make their life full of happiness, peace and contentment. When their mind is improved with soft skills, they can get what they have needed. We need to make our students free from such evil thoughts like the Buddha. The product of TVET has been burdened with the above evil thoughts, feelings and behaviors. A genuine manpower only can get reliable output. We can produce quality manpower who is free of tension and be able to reduce the problems between and among colleagues. The Buddha is the pioneer of peace in the world so we need to implant such ideas and views to our students to make them responsible, accountable and dutiful.

Nowadays the demand of employer is also same like the understanding of those unemployed students. Though they have the feeling of lack in their life, no stakeholders have tried to maintain it at all. The way is certain that we can't reach nowhere disposing hard skills only in the mind of students. It needs meaningful change from the side of TVET institutions to make people flexible to perform multiple tasks. Focusing on hard skills has become a ritual by the TVET institutions; we need to break the tradition somehow to make it suitable as per the demand of new era. If we could revitalize Buddhist philosophy of spirituality in TVET institutions, we can produce mindfulness in personnel. The demand of employer is also addressed along with the possibility of employment for students.

\section{Conclusion}

We can address the issue of soft skills in TVET institutions making it contemporary enhancing labors with communication skills, team work skills, and problem solving skills. Labors are important part of the organization, unlike in the past when they were only taken as subsidiary elements of production. They should perform more than machinery works of the organization to achieve greater output. Thus the need of soft skills has been becoming popular at present context. Hard skills only have produced technical manpower who have lacked interpersonal skills that has negative impact in the progression of the organization. To implant such skills we can take help of Buddhist philosophy of spirituality which has enhanced filial piety among them so that they can perform well in their work. It also helps to develop mindfulness in personnel so that they would feel work as their own and employer and customers as their friends or relatives. The often ignored soft skills have taken space in TVET sector after the 1990s as technical skills only increased more unemployment in the labour market. Soft skills are life-line of workers whereas hard skills are the structure of a body. It is supported that soft skills reside as heart to pump blood throughout the body; or it has worked as software of the computer hardware system.

Their ability to master soft skills is key to being able to successfully navigate the various pathways of work (Youth Employment Funders Group, 2017).

Present problem of employers and employees can be solved if we can instruct soft skills to those who have got technical knowledge. The demand of employer is also much appraisable as they are the job providers and they have been greatly aware about the need of industries. It helps to reduce the delirium of the workplace that often happens among employer, employee and service takers. Work place is an abode of the employer and the employee which has provided them the life running substance. Though they have different entitlements, they have been facing the same fate in which failure leads to further disaster. Or they have been travelling in a same boat to cross the river. If conflict inflicts them, their boat would sink down. Soft skills help to solve all those unnecessary grievances making personnel more amicable, cooperative, affectionate, and full of fraternity: the core aspect of Buddhist teaching.

\section{References}

Baral, R. \& Sapkota, S. (2015). Factors influencing migration among Nepalese nurses. Journal of chitwan medical college. 5(12), 25-29.

Cheng, F. K. (2017). Buddhist insights into life and death: overcoming death anxiety. Athens journal of social sciences. 67-78. 
Cresswell, J. W. (2009). Research design: Qualitative, quantative and mixed methods approaches. Los Angeles: Sage publication, Inc.

CTEVT. (2016). CTEVT Fact Sheet. CTEVT research and information division. Bhaktapur.

CTEVT. (2016). Labour market survey: Analysis of Emerging Needs of Technical Human Resources in the Country. CTEVT Research and Information Division, Bhaktapur.

Dorzhigushaeva, O., Dondukov, B. \& Dondukova, G. (2017). Buddhist religious education in the context of modern Russian policy of multicultural education: A case of the Republic of Buryatia. Journal of social studies education research. 8(2), 80-99.

Filanders University. (n. d.). Buddhist identities. filanders.edu.au/cdip.

Gupta, B. S., Shrestha, S. \& Thulung B. K. (2014). Patient's perception towards quality nursing care. Journal of Nepal health research council. 12(27), 83-87.

Idris, A. \& Mbudai, Y. (2017). Technical and vocational education: Challenges towards youth empowerment in Kano State-Nigeria. Journal of technical education and training, 9 (1).

Jha, W. (2012). TVET of Nepal in the World of Work. (R. Karki, Ed.) Technical and vocational education and training development journal , 1 (12), 81-87.

Johan et al. (2017). To identify the causes of stress among nurses working in intensive care unit of ittefaq hospital Lahore. International Journal of Social Science and Management. 4(2), 96-109; DOI: 10.3126/ijssm.v4i2.17159

Kung, C. (n.d.). Buddhism as an education. Buddha dharma education inc.

Kwon, D. (2009). Human capital and its measurement. The 3rd OECD World Forum on "Statistics, Knowledge and Policy", Busan, Korea.

LaFever, K. (2016). Active compassion: Empowering Buddhist nuns through STEM education. The Asian conference on education \& international development 2016 official conference proceedings. Miami University, USA.

Luanglath, I. (2015). Buddhist theory of education for e-learning. The twelfth international conference on elearning for knowledge-based society. Bangkok University.

Maclean, R., \& Pavlova, M. (2013). Vocationalization of secondary and higher education: pathways to the world of work. Revisiting global trends in TVET: Reflections on theory and practice, 40-85.

McTaggart, R. (1994). Participatory action research: Issues in theory and practice. Educational action research, $2(3)$.

Mohd Affandi et. al. (2017). Establishing the Malaysian contractors' soft skills requirements for construction management graduates: Applying the rasch measurement model. Journal of technical education and training, 9(1), 62-78

Mohd Noor, S. N. F. Md Tab, F. \& Kamarulzaman, R. (2017). Exploring job interview skills of future engineers: Application of appraisal analysis assessment and verbal impression management. Journal of technical education and training, 9(1), 87-97.

Munishi, E. J. (2016). Factors contributing to lack of employable skills among technical and vocational education (TVET) Graduates In TANZANIA. Business Education Journal. I(2), 1-19

Neupane, M. S. (2013). Is investing in vocational training profitable? Analysis of rate of return. (R. Karki, Ed.) Technical and vocational education and training development journal , 1 (13), 74-80.

Neupane, B. R., \& Pradhan, H. K. (2014). Soft skill Gaps in CTEVT Curriculum Guides. (R. Karki, Ed.) Technical and Vocational Education and Training Development Journal, 1 (14), 48-52.

Ng, V. \& Yugen, M. (2015). How is Buddhism relevant to career counselling in an international high school in Hong Kong? A counsellor's reflection. International journal for the advancement of counseling.

Renold, U., \& Caves, K. (2017). Constitutional reform and its impact on TVET governance in Nepal. Geneva: KOF studies.

Rood, R. V. (2014). Identification for EU support to TVET sector. Hempstead: HTSPE Limited.

Shrestha, P. (2016). "Challenges and impacts of transforming paper-based nursing documentation into electronic form: A study in Nepal." The Arctic University of Norway.

Sirimanne, C. R. (2016). Buddhist and women-the Dhamma has no gender. Journal of International women's studies. 18(1), 273-292.

SOLID Nepal. (2012). Barriers to effective policy implementation and management of human resources for health in Nepal: Health workforce performance and accountability. Lalitpur, Nepal.

Tamara, D. (2017). Meditation in modern education: Outlining a pilot programme from Australia. In Dasho Karma Ura, Dorji Penjore \& Chhimi Dem (Eds). Mndala of $21^{\text {st }}$ century perspectives: Proceedings of the international conference on tradition and innovation in vajrayana Buddhism. 205-221.

Tikly, L. (2013). Reconceptualizing TVET and development: a human capability and social justice approach. Revisiting global trends in TVET: Reflections on theory and practice , 1-39.

Thulung, B.K. (2015). Perception of quality nursing care among patient and nurses in a teaching hospital. Journal 
of Chitwan Medical college. 5(13), 40-45.

Wan Muda, et. al. (2016). Developing a leadership capability for team leaders in the construction industry: A concept for organizational success. Journal of technical education and training. 8(2), 22-29.

Yin, R. K. (2014). Case study research design and methods. Los Angeles: Sage publications, Inc. 